\title{
Pengaruh maloklusi gigi anterior terhadap status psikososial pada siswa SMA Negeri 1 Luwuk
}

\author{
${ }^{1}$ Dediyanto C. Sambeta \\ ${ }^{2}$ P.S Anindita \\ ${ }^{2}$ Juliatri
}

\author{
${ }^{1}$ Kandidat skripsi Program Studi Pendidikan Dokter Gigi Fakultas Kedokteran \\ ${ }^{2}$ Program Studi Pendidikan Dokter Gigi Fakultas Kedokteran \\ Universitas Sam Ratulangi Manado \\ Email: dedysambeta@gmail.com
}

\begin{abstract}
Facial appearance, especially the eye and mouth part, has the highest level in affecting people perception of aesthetic. Adolescence is a stage of self-identity formation. Adolescent face and mandible teeth aesthetic play an important role in forming a self-concept and pride. An unattractive appearance of face and the mandible teeth has a horrible impact on psychosocial development in adolescence. This study aimed to obtain the impact of anterior malocclusion on psychosocial status of SMA Negeri 1 Luwuk students. This was an analytical observational study with a cross sectional design. Subjects were obtained by using purposive sampling. This study was conducted in 2014 on September 14 to Oktober 10. Data were collected from the subjects with anterior malocclusion who underwent intraoral examination. There were 50 subjects selected to fill the PIDAQ questionnaire. The Spearman correlation test showed the coefficient of correlation $(r)=0.176$, which indicated that the anterior malocclusion had no impact towards psychosocial status of SMA Negeri 1 Luwuk students. Conclusion: Anterior malocclusion had no impact towards psychosocial status of SMA Negeri 1 Luwuk students.

Keywords: anterior malocclusion, adolescence, psychosocial status, psychosocial impact, PIDAQ
\end{abstract}

\begin{abstract}
Abstrak: Penampilan wajah, terutama pada bagian mata dan mulut, memiliki tingkatan tertinggi dalam memengaruhi persepsi estetika seseorang. Masa remaja merupakan tahap pembentukan identitas diri. Estetika wajah dan gigi-geligi remaja berperan penting dalam pembentukan konsep diri dan harga diri. Tampilan wajah dan gigi-geligi yang tidak menarik mempunyai dampak yang tidak menguntungkan pada perkembangan psikologis dan sosial seorang remaja. Penelitian ini bertujuan untuk mengetahui pengaruh maloklusi gigi anterior terhadap status psikososial siswa SMA Negeri 1 Luwuk. Jenis penelitian ini observasional analitik dengan desain potong lintang. Sampel diperoleh dengan metode purposive sampling. Pengambilan data dilakukan dengan memeriksa subjek yang mengalami maloklusi anterior. Penelitian ini dilakukan sejak 14 September-10 Oktober 2014. Terdapat 50 siswa sebagai subyek dan mengisi kuesioner PIDAQ. Uji Korelasi Spearman menunjukkan koefisien korelasi $(r)=0,176$, yang berarti tidak ada pengaruh antara maloklusi gigi anterior terhadap status psikososial pada siswa SMA Negeri 1 Luwuk. Simpulan: Tidak terdapat pengaruh maloklusi gigi anterior terhadap status psikososial pada siswa SMA Negeri 1 Luwuk.
\end{abstract}

Kata kunci: maloklusi anterior, remaja, status psikososial, PIDAQ 
Penampilan wajah, terutama pada bagian mata dan mulut memiliki tingkatan tertinggi dalam memengaruhi persepsi estetika seseorang. Tetapi, dibandingkan dengan bagian yang lain, ketidakpuasan terhadap estetika wajah seringkali lebih disebabkan oleh keadaan gigi geligi. ${ }^{1}$

Berbagai penyakit maupun kelainan gigi dan mulut dapat memengaruhi berbagai fungsi rongga mulut, salah satunya adalah kelainan susunan gigi atau yang disebut dengan maloklusi. Maloklusi dapat menyebabkan tampilan wajah yang buruk bila tidak dikoreksi. ${ }^{2,3}$

Masa remaja merupakan tahap pembentukan identitas diri. Estetika wajah dan gigi-geligi remaja berperan penting dalam pembentukan konsep diri dan harga diri. Menurut Kustiawan penampilan wajah yang tidak menarik mempunyai dampak yang tidak menguntungkan pada perkembangan psikologis seorang remaja. Tingkat keparahan maloklusi pada remaja berdampak pada interaksi sosial, keadaan psikologis, rasa percaya diri, serta ketidakpuasan akan penampilan. ${ }^{1,4}$

Psikologi sosial merupakan suatu cabang psikologi yang secara khusus memuat lapangan studi tentang tingkah laku individu sebagai suatu fungsi dari rangsangan sosial. ${ }^{5}$ Penelitian DiBiase et al. pada tahun 2001 menyatakan bahwa anakanak dengan kasus maloklusi lebih memungkinkan menjadi korban tindasan teman-temannya. Penindasan di sekolah dapat memengaruhi bukan hanya psikososial sekarang ini, namun juga psikososial seseorang di masa yang akan datang. $^{6}$

\section{METODE PENELITIAN}

Jenis penelitian ini ialah observasional analitik dengan desain potong lintang. Penelitian ini dilaksanakan di SMA Negeri 1 Luwuk sejak 14 September - 10 Oktober 2015. Populasi penelitian ini ialah seluruh siswa SMA N 1 Luwuk. Subyek penelitian ialah 50 orang siswa yang diambil berdasarkan kriteria inklusi dan eksklusi.

Setelah melewati proses seleksi, setiap siswa yang memenuhi kriteria pemilihan sampel dipanggil dan dipersilahkan duduk pada bangku yang telah disediakan. Posisi pemeriksa dan anak saling berhadapan.

Pengambilan data siswa dilakukan di sekolah pada ruang UKS pada jam istirahat maupun ketika jam pelajaran kosong. Setelah mengisi data identitas siswa, siswa diperiksa subjek mengalami maloklusi gigi berdasarkan klasifikasi Angle. Pemeriksaan lanjut ialah menentukan maloklusi dengan karakteristik maloklusi anterior menurut Dewey. Setelah itu dicatat dalam formulir pemeriksaan dengan memberi tanda centang pada kolom klasifikasi. Tiap subjek penelitian yang memenuhi kriteria inklusi selanjutnya akan dibagikan kuesioner penelitian PIDAQ untuk diisi.

\section{HASIL PENELITIAN}

Berdasarkan penelitian didapatkan 50 orang reponden penelitian dengan distribusi berdasarkan kategori umur (Tabel 1) dan jenis kelamin (Tabel 2).

Berdasarkan Tabel 1, responden pada kategori umur 15 tahun memiliki persentase terbesar (50\%).

Tabel 1. Distribusi Responden Berdasarkan Kategori Umur

\begin{tabular}{ccc}
\hline Umur & Frekuensi & $\begin{array}{c}\text { Persentase } \\
(\%)\end{array}$ \\
\hline 15 tahun & 25 & 50 \\
16 tahun & 24 & 48 \\
17 tahun & 1 & 2 \\
18 tahun & 0 & 0 \\
Total & 50 & 100 \\
\hline
\end{tabular}

Berdasarkan Tabel 2, responden didominasi oleh jenis kelamin perempuan (74\%).

Tabel 2. Distribusi Responden Berdasarkan Kategori Jenis Kelamin

\begin{tabular}{ccc}
\hline $\begin{array}{c}\text { Jenis } \\
\text { Kelamin }\end{array}$ & Frekuensi & $\begin{array}{c}\text { Persentase } \\
(\%)\end{array}$ \\
\hline Laki-laki & 13 & 26 \\
Perempuan & 37 & 74 \\
Total & 50 & 100 \\
\hline
\end{tabular}


Berdasarkan hasil penelitian, diperoleh gambaran status psikososial siswa berdasarkan status maloklusi anterior. Gambar 1 menunjukkan bahwa subyek dengan status psikososial sedang pada kasus maloklusi Dewey Klas III Tipe II (gigi insisif bawah berjejal dan berada di lingual dari insisif atas) ialah yang paling besar, yaitu sebanyak 9 orang (18\%).

Berdasarkan hasil penelitian, diperoleh hasil statistik tentang pengaruh status maloklusi anterior dengan status psikososial pada siswa SMA Negeri 1 Luwuk. Berdasarkan Tabel 3, tidak terdapat pengaruh antara status maloklusi berdasarkan Modifikasi Dewey terhadap status psikososial pada siswa SMA Negeri 1 Luwuk, dengan nilai koefisien korelasi $\mathrm{r}=$ 0,176 yang menunjukkan hampir tidak ada hubungan $(r=0,00-0,20)$.

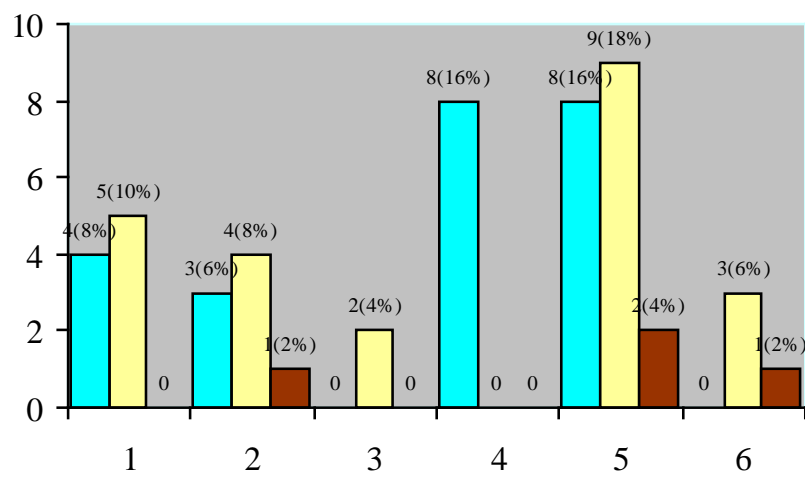

$\square$ TINGGI $\square$ SEDANG $\square$ RENDAH

Keterangan :

1. Maloklusi Dewey Klas I Tipe I

2. Maloklusi Dewey Klas I Tipe II

3. Maloklusi Dewey Klas I Tipe III

4. Maloklusi Dewey Klas III Tipe I

5. Maloklusi Dewey Klas III Tipe II

6. Maloklusi Dewey Klas III Tipe III

Gambar 1. Status Psikososial Siswa Berdasarkan Status Maloklusi Anterior

Tabel 3. Pengaruh Status Maloklusi Anterior Dengan Status Psikososial Pada Siswa SMA Negeri 1 Luwuk

\begin{tabular}{|c|c|c|c|c|c|c|c|c|c|}
\hline \multirow{3}{*}{ Maloklusi Dewey } & \multicolumn{6}{|c|}{ Status Psikososial } & \multicolumn{2}{|c|}{ Total } & \multirow[t]{3}{*}{$\mathrm{r}$} \\
\hline & \multicolumn{2}{|c|}{ Tinggi } & \multicolumn{2}{|c|}{ Sedang } & \multicolumn{2}{|c|}{ Rendah } & $\mathrm{n}$ & $\%$ & \\
\hline & $\mathrm{n}$ & $\%$ & $\mathrm{n}$ & $\%$ & $\mathrm{n}$ & $\%$ & & & \\
\hline Klas I Tipe I & 4 & 8 & 5 & 10 & - & - & 9 & 18 & \\
\hline Klas I Tipe II & 3 & 6 & 4 & 8 & 1 & 2 & 8 & 16 & \\
\hline Klas I Tipe III & - & - & 2 & 4 & - & - & 2 & 4 & \\
\hline Klas III Tipe I & 8 & 16 & - & - & - & - & 8 & 16 & $0,1 / 6$ \\
\hline Klas III Tipe II & 8 & 16 & 9 & 18 & 2 & 4 & 19 & 38 & \\
\hline Klas III Tipe III & - & - & 3 & 6 & 1 & 2 & 4 & 8 & \\
\hline Total & 23 & 46 & 23 & 46 & 4 & 8 & 50 & 100 & \\
\hline
\end{tabular}

\section{BAHASAN}

Penelitian ini dilaksanakan di SMA Negeri 1 Luwuk, tanggal 14 September sampai 10 Oktober 2015. Dalam penelitian ini diperoleh 50 orang siswa yang bersedia menjadi subyek penelitian dan memenuhi kriteria inklusi. Berdasarkan penilaian statistik tidak terdapat pengaruh maloklusi 
anterior terhadap status psikososial siswa SMA Negeri 1 Luwuk.

Subyek penelitian ii yang memiliki status psikososial rendah hanya $8 \%$ dibandingkan dengan mereka yang memiliki status psikososial tinggi dan sedang dengan persentase masing-masing 46\%. Hasil ini sejalan dengan penelitian De Paula et al. $^{7}$ terhadap 301 sampel remaja dalam rentang usia 13 hingga 20 tahun, mereka menemukan bahwa meskipun ketidakpuasan dengan penampilan gigi amat berkaitan dengan tingkat keparahan dari susunan gigi, tidak jarang didapati beberapa pasien dengan maloklusi parah, merasa puas dengan estetika gigi mereka. ${ }^{7}$ Asumsi penulis tentang penyebab hal tersebut ialah pengetahuan dan kesadaran siswa di SMA Negeri 1 Luwuk tentang maloklusi masih kurang, sehingga memengaruhi persepsi subjektif mereka akan maloklusi. Hal ini terlihat pada beberapa responden dengan kasus maloklusi rahang atas justru menganggap keadaan gigi mereka lebih menarik dibanding jika tidak mengalaminya. Pendapat ini sejalan dengan penelitian Dewi $^{2}$ yang meneliti kepada 413 siswa di Medan dan mendapatkan bahwa 82,6\% responden yang diteliti mempunyai keyakinan mengenai susunan gigi-geliginya termasuk dalam kategori baik.

Penyebab lain yang menjadi asumsi penulis ialah proses sosialisasi di lingkungan siswa-siswi SMA Negeri 1 Luwuk yang tidak terlalu memerhatikan kondisi gigi-geligi sehingga sebagian besar dari mereka merasa kondisi gigi-geligi bukan menjadi penghalang dalam bersosialisasi. Meskipun demikian, ada dari antara siswa-siswi tersebut yang sering dikomentari karena gigi berjejal yang parah. Pada beberapa subjek dengan gigi protrusi yang parah juga pernah dikomentari oleh teman-temannya.

Walaupun menurut Dibiase, remaja yang mempunyai bentuk wajah yang tidak menarik akibat adanya maloklusi akan menyebabkan pengalaman psikis yang tidak baik, tetapi prinsip penting dari psikologi sosial ialah meskipun karakteristik individu memengaruhi seseorang ketika melakukan sesuatu, situasi sosial yang sering menjadi penentu kuat terhadap perilaku daripada kepribadian. Individu cenderung merasa nyaman dengan diri sendiri ketika memiliki interaksi sosial yang memadai dan bahwa mereka diterima dan dipedulikan oleh orang lain. Jika kebutuhan untuk penerimaan sosial tidak terpenuhi mereka dapat memiliki harga diri yang rendah. ${ }^{2,8,9}$ Faktor inilah yang memengaruhi persepsi subjektif siswa SMA Negeri 1 Luwuk. Ketika tidak terdapat gangguan dalam aspek penerimaan sosial dari teman-teman lain akibat proses sosialisasi yang tidak memerhatikan kondisi gigi-geligi, maka siswa tersebut memiliki perasaan aman akan dirinya sehingga selama perasaan aman ini tetap ada, tidak akan memengaruhi kondisi psikososial bagi sebagian besar siswa sekalipun mereka mengalami maloklusi.

\section{SIMPULAN}

Dari hasil penelitioan dapat disimpullkan bahwa tidak terdapat pengaruh maloklusi anterior terhadap status psikososial siswa SMA Negeri 1 Luwuk pada tahun 2015.

\section{SARAN}

Bagi penelitian lanjut diperlukan jumlah sampel yang lebih banyak serta meninjau lebih lanjut faktor-faktor lain seperti aspek tingkat pendidikan ora ng tua yang mungkin dapat memengaruhi status psikososial remaja.

\section{DAFTAR PUSTAKA}

1. Arsie RY. Dampak Berbagai Karakteristik Oklusi Gigi Anterior Terhadap Status Psikososial Remaja Awal [Tesis]. Jakarta: PPDGS Ortodonti FKG Universitas Indonesia; 2012. p.1-19

2. Dewi O. Analisis hubungan maloklusi dengan kualitas hidup pada remaja SMU kota Medan tahun 2007 [Tesis]. Medan: Sekolah Pascasarjana Universitas Sumatera Utara; 2008. p. 13,65-89

3. Wijayanti $\mathbf{P}$, Krisnawati, Ismah $\mathbf{N}$. Gambaran maloklusi dan kebutuhan 
perawatan ortodonti pada anak usia 911 tahun. Jurnal PDGI. 2014;63(1):259.

4. Wagiran DIL. Kualitas hidup remaja SMA Negeri 6 Manado yang mengalami maloklusi [Skripsi]. Manado: Progam studi pendidikan dokter gigi Universitas Sam Ratulangi; 2014. p. 2-12

5. Liling DT. Hubungan kasus maloklusi gigi anterior dengan status psikososial pada pelajar SMP di Makassar [Skripsi]. Makassar: Fakultas Kedokteran Gigi: Universitas Hasanuddin; 2014. p. 2-16

6. Sari IT. Pengaruh perawatan ortodontik cekat terhadap tingkat kepercayaan diri pelajar sekolah menengah atas Yayasan Pendidikan Al-Ma'soem, Jatinangor
Sumedang tahun 2012 [Skripsi]. Bandung: Program Studi Kedokteran Gigi Universitas Kristen Maranatha; 2012. p. 2.

7. de Paula DF, Santos NCM, da Silva ET, Nunes MdF, Leles CR. Psychosocial impact of dental esthetics on quality of life in adolescents. Angle Orthod. 2009. 79 (6):1188-93.

8. Saylor. Principles of Sociological Inquiry Qualitative and Quantitativa Methods. p. 7-133 [online]. [cited 2015 May 17]. Available from: http://www.saylor.org/books

9. Santrock J.W. Adolescence. 6th Ed. Adelar SB, translator. Jakarta: Penerbit Erlangga, 2003; p. 228-338. 